\title{
NUTRITIONAL KNOWLEDGE OF SCHOOL CHILDREN
}

\section{By}

Naduni Dushanthi Karalliyadda

Thesis submitted to the University of Sri Jayewardenepura for the award of the Degree of Master of Science in Food Science \& Technology 


\section{DECLARATION}

The work described in this thesis was carried out by me under the supervision of Prof.Authur Bamunuarachchi and Dr.K.K.D.S.Ranaweera, and a report on this thesis has not been submitted to any university for another degree

$24-1 !-06$

... Wulligedda...............

Date

Naduni Dushanthi Karalliyadda 
We,Prof.Authur Bamunuarachchi and Dr.K.K.D.S.Ranaweera jointly certify that the above statement made by the candidate is true and that thesis suitable for submission to the University for the purpose of evaluation.

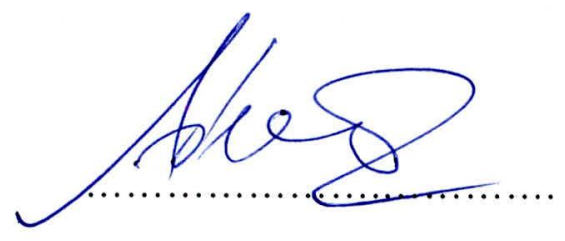

Signature

Supervisor

Prof.Authur Bamunuarachchi

FORMER HEAD/DEPARTMENT OF FOOD SCIENCE AND TECHNOLOGY

UNIVERSITY OF SRI JAYEWARDENEPURA

SRI LANKA

Supervisor

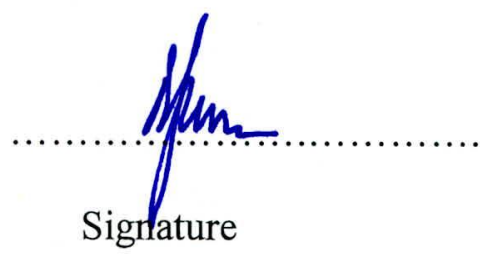

Dr.K.K.D.S.Ranaweera

HEAD/DEPARTMENT OF FOOD SCIENCE AND TECHNOLOGY

UNIVERSITY OF SRI JAYEWARDENEPURA

SRI LANKA 


\section{TABLE OF CONTENTS}

List of figures $\quad \mathrm{V}$

List of Tables $\quad$ vi

Acknowledgement vii

Abstract viii

Chapter - 1

Introduction

1.1 General 1

1.2 Is nutritional knowledge related to food behaviours 3

1.3 Maternal nutritional knowledge and child nutritional status 4

$\begin{array}{ll}1.4 \text { Poor Nutrition Knowledge } & 6\end{array}$

$\begin{array}{ll}\text { 1.4.1 Food classifications } & 7\end{array}$

$\begin{array}{ll}\text { 1.5 Significance and need of the survey } & 7\end{array}$

$\begin{array}{lr}1.6 \text { Objectives of the survey } & 8\end{array}$

$\begin{array}{lr}\text { 1.7 Specific Objectives } & 8\end{array}$

Chapter - 2

1.8 Literature Review 9

$\begin{array}{ll}\text { 1.9.School Children and adolescent } & 12\end{array}$

$\begin{array}{ll}2.0 \text { Nutrients for the Growing Years } & 13\end{array}$ 
$\begin{array}{ll}2.1 \text { Protein } & 17\end{array}$

$\begin{array}{ll}2.2 \text { Lipids } & 18\end{array}$

$\begin{array}{ll}2.3 \text { Carbohydrate } & 20\end{array}$

$\begin{array}{ll}2.4 \text { Vitamins } & 21\end{array}$

$\begin{array}{ll}2.5 \text { Minerals } & 23\end{array}$

$\begin{array}{ll}2.6 \text { Fibre } & 24\end{array}$

$\begin{array}{lr}\text { 2.7.Vegetables } & 25\end{array}$

$\begin{array}{lr}2.8 \text { Fruits } & 28\end{array}$

$\begin{array}{ll}2.9 \text { Water } & 28\end{array}$

Chapter - 3

Experimental

$\begin{array}{ll}\text { 3.1.Study area } & 30\end{array}$

$\begin{array}{ll}\text { 3.2 Design of the study } & 30\end{array}$

$\begin{array}{ll}3.3 \text { Period of study } & 30\end{array}$

$\begin{array}{ll}\text { 3.4 Study Population } & 30\end{array}$

$\begin{array}{ll}\text { 3.5 Sample Size Calculation } & 30\end{array}$

$\begin{array}{ll}\text { 3.6 Sampling Procedure } & 30\end{array}$

3.6.1 Importance of sampling $\quad 31$

3.6.2.Stratified Random Sampling $\quad 31$

3.7.Study Instrument $\quad 31$ 
Chapter - 4

Results

4.0 Find whether the knowledge varying with different categories

4.01.Gender

4.02.Age-School

4.03.Age-Total no of Children $\quad 54$

4.1 Finding the knowledge in consumption of nutritions 55

$\begin{array}{ll}4.2 \text { Influencing factors } & 61\end{array}$

4.3 Nutritional value of the favourite meal 63

$\begin{array}{ll}\text { 4.4 Meal time variation } & 65\end{array}$

$\begin{array}{ll}\text { 4.5Variation of parents education level } & 67\end{array}$

$\begin{array}{ll}\text { 4.6Variation of parents income } & 70\end{array}$

$\begin{array}{ll}\text { 4.7 Variation of parents income with no of children } & 73\end{array}$

$\begin{array}{ll}\text { 4.8 Variation of expenditure on food } & 75\end{array}$

4.9 Variation of expenditure on food vs income 78

Chapter - 5

$\begin{array}{lr}\text { Discussion } & 80\end{array}$ 
Chapter - 6

Conclusion

References 
Annexture - 1

Annexture - 2

Annexture - 3

Annexture - 4

Annexture - 5

Annexture - 6

94

Annexture - 7

95

Annexture - 8

96

Annexture - 9

97

Annexture - 10

98

Annexture - 11

99

Annexture - 12

100

Annexture - 13

101 


\section{LIST OF FIGURES}

Figure-1-2 Gender of respondents 34-35

Figure 3-4 Variation of consumption of nutritions against gender $\quad$ 45-46

Figure 5-13 Knowledge variation with age 48-54

Figure 14-22 knowledge in consumption of nutritions $\quad 62-67$

$\begin{array}{llr}\text { Figure 23-25 Influencing factors } & 68-69\end{array}$

$\begin{array}{lll}\text { Figure 26-28 Nutritional value of the favourite meal } & \text { 70-71 }\end{array}$

$\begin{array}{lll}\text { Figure 29-31 } \quad \text { Meal time variation } & \text { 72-73 }\end{array}$

Figure 32-34 $\quad$ Variation of parents education level

$\begin{array}{lll}\text { Figure 35-37 } \quad \text { Variation of parents income } & \text { 75-77 }\end{array}$

Figure 38-40 Variation of parents income with no of children $\quad$ 77-79

Figure 41-43 Variation of expenditure on food $\quad 79-80$

Figure 44-46 Variation of expenditure on food vs income 81-82 


\section{LIST OF TABLES}

Table-1 A pattern for daily food choices

Table-2

Energy and some nutrients supplied by $100 \mathrm{~g}$ edible portion of Vegetables

Table-3 Interested to have knowledge on nutrition

Table-4

Sources of gathering knowledge on nutrition

Table-5

Suggestions to improve Nutritional Knowledge

Table-6

Knowledge on general statement

Table-7

Knowledge on general statement

Table- 8

Knowledge on general statement

41 


\section{ACKNOWLEDGEMENT}

I wish to express my sincere thanks and heart felt gratitude to my supervisors Prof.Arthur Bamunuarachchi and Dr.K.K.D.S Ranaweera,Head/Department of Food Science and Technology of University of Sri Jayawardenepura .

Also I thankful to Mr and Mrs.Wijerathne who given me the fullest support to complete this thesis.

I would like to thank Miss Purnima of Industrial Technological Institute,for her guidance and assistance given to me in several ways in during the period of this survey.

I wish to express my sincere gratitude with deep appreciation to my dearest parents,my husband and my relatives for their fullest coorperation given to me to pursue this study.There are numerous others whose name though not mentioned to whom thanks are due 


\title{
STUDY OF NUTRITIONAL KNOWLEDGE OF SCHOOL
}

\section{CHILDREN}

\author{
Naduni Dushanthi Karalliyadda
}

\begin{abstract}
$\underline{\text { ABSTRACT }}$
This study conducted to assess the knowledge on nutrition of school children in three different schools. Selected sample consist of two Government Schools and a one International School.

School meals can make an important contribution to the energy intake of school children.Though the school children were consuming food this survey was carried out to find out whether they were knowledgable in nutritions.

In addition, it focused on gender,age group,type of school,total no of children,general, knowledge on each nutrient. Inaddition to that selected sample had a relationship between parents income with no of children, variation of expenditure on food vs income, Nutritional value of the favourite meal and the influencing factors for selecting a meal.
\end{abstract}

The sample population divided according to schools and standard comprehensive closeended questionniers administered to collect the data required. The data collected within two months. The collected data was analyzed using Chi-square Distribution Procedure. This survey revealed that the knowledge on nutrition does not varied with gender,age,total no of children But varies with the type of school. 
There is no difference in knowledge between females and males. According to Chi square method $\left(\mathrm{x}_{\text {cal }}^{2}\right)=0.8$, degrees of freedom $=1$.

There is no difference in knowledge between different age groups and total no of children.. But knowledge is different among the schools.

Wokshops were the best source of gathering knowledge on nutrition. Whereas the most of them suggested Video/Films were the best method of improving knowledge on nutrition.

Although sample population had knowledge about nutrition ,unfortunately following week points notified.Knowledge on Protein deficiency $37.30 \%$, Knowledge on Vitamin $\mathrm{B}_{12}$ $35.19 \% . ; 36.57 \%$ were known about Processing of fruits, whereas $37.45 \%$ were known about a Vegatarian diet.

Furthermore 79.32\% were known about Proteins, $77.90 \%$ identified,Carbohydrates, $61.63 \%$ were known about Fibre,while $62.85 \%$ were known about Uses of Fibre, $68.15 \%$ were known about Minerals,59.88\% about Vitamins,51.09\% about Iron, 49.01\%known on Processing of rice, $59.89 \%$ known about Parboiled rice , $42.55 \%$ were known about Processed food.Furthermore 64.64\% were known about Processing of green leaves. $55.14 \%$ identified uses of water for the human body, 51.01\% were known about Milk, $76.37 \%$ were known about fruits, $73.76 \%$ identified Cholesterol, $53.55 \%$ were known about lipidsWhereas $65.01 \%$ were known about fish..In addition to that, while $70.24 \%$ known about Vegetables.64.44\% identified about a balanced diet 


\section{CHAPTER-1}

\section{INTRODUCTION}

\subsection{What is nutrition?}

The council on Food and Nutrition of the American Medical Association defines nutrition as "The science of food,the nutrients and the substances therein,their action,interaction, and balance in relation to health and disease, and the process by which the organism ingests, digests,absorbs,transport,utilizes, and excretes food substances."

\section{(Wickramanayaka-Nutrition and Dietetics)}

Food provides both the energy and the materials needed to build and maintain all body cells.Nutrients are the nourishing substances we must obtain from food .These essential substances are vital for growth and maintenance from infancy to adulthood.For a nutrient to be considered essential ,two characteristics are needed.First it's omission from the diet must lead to a decline in certain aspects of human health,such as function of the nervous system.Second, if the omitted nutrient is restored to the diet before permanent damage occurs, those aspects of human health hampered by it's absence should regain normal function.

carbohydrate,proteins, lipids, vitamins,minerals and water make up six classes of nutrients found in food.Nutrients can be further sorted in to three groups(1)those that primarily provide us with energy-Carbohydrates,proteins,lipids,(2)those that are important for growth, development, and maintenance-proteins, lipids, vitamins, minerals, water(3)those that act to keep body functions running smoothly-proteins, lipids, vitamins, mineralsand water.Some overlap exists between these groupings. The energy yielding nutrients make up a major portion of most food.

A food may be defined as any substance which,when taken in to the body enables an organisms to grow and maintain health.The term food ,therefore includes all solid and 
liquid foods, water and substances dissolved there in.Food carries out these functions in three ways.

1.by supplying material for the production of energy.

2.by supplying material for building up of new tissue and for repair of tissue.

3.by subblying substances which enable and even stimulate the body to produce energy and to grow.

(Wickramanayaka-Nutrition and Dietetics)

Nutrition also involves the study of man in relation to his food:his food beliefs and practices and the influence of social,religious and economic factors on his eating pattern which,in turn ,may affect his health and wellbeing .

Studies done in developing countries suggested that lack of knowledge about food is the major cause for malnutrition and food related diseases rather than the availability of foods.

Poor knowledge on nutrition ,low literacy rate,taboos,cultural practices,religion believing and myths lead to malnutrition.

In Sri Lanka as in other developing countries ,malnutrition and ill health are associated with a cluster of related and often coexistent factors.such as limited resources for the basic needs.of food and shelter,poor environment where infections and vector -borne diseases are widespread, poor access to safe water, large family size and a low level of education (especially of the female).

These factors act synergistically in the progression and perpetuation of undernutrition.

Undernutrition.could have a lasting effect on family development.It can result in inefficiency and low productivity.Low productivity leads to low income and economically and socially deprived households or community. 